as to "curves", the "curves of supply and demand" had much less to do with a man's control of the market, than the curves of his profile. He himself had earned only $£ 100$ in the previous twelve months, whereas, with our host's resolute curve of the chin, he would be making $£ 10,000$ a year. And he proceeded to illustrate his point, amid the embarrassed laughter of the company, by drawing their own profiles in lively caricature on the blackboard.'

These, however, were only preliminary flourishes of the cap and bells; and they did not prevent Wicksteed, then or later, from doing justice to the serious thinking and purpose which Mr Shaw's coruscations have often served rather to conceal than to illuminate. At these meetings, in any case, where economists so distinguished as Foxwell, Graham Wallas ${ }^{1}$ and others were present, the two coryphæi of the discussion were Wicksteed and Shaw; and Mr Fripp declares that their encounters were the most brilliant he has ever heard.

\title{
NOTE
}

1. Herbert Somerton Foxwell (1849-1936) became Professor of Political Economy at University College, London, in 1891. Graham Wallas (1858-1932) was a student at Oxford with Sydney Olivier and worked as a schoolmaster and university extension lecturer before joining the staff of the London School of Economics in 1895. He became a member of the Fabian Society in 1886 and together with Webb, Shaw and Olivier formed a group which determined its early course.

\section{Marx in the Original}

\author{
SIDNEY WEBB
}

From The Letters of Sidney and Beatrice Webb, ed. Norman MacKenzie, 3 vols (Cambridge: Cambridge University Press, 1978) I, 93. On 17 August 1885 Webb wrote to Graham Wallas proposing to join him for a holiday in Germany, where Wallas was living to learn the language.

I have begun to teach German to G. B. Shaw, the embryo-novelist. He knows 'and' and 'the' only. We began Marx, Kapital, vol. 2 - not the easiest of books. We read two pages in two hours, accompanying each word with a philological dissertation. It was really very interessant to me. 